\title{
Dimensi "Kejahatan Korporasi" dan Reaksi Sosial
}

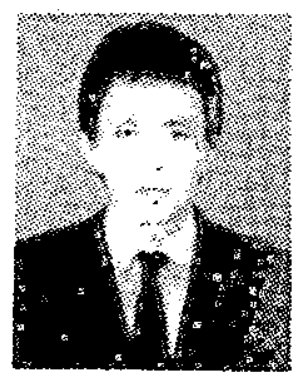

Suparman Marzuki

Harus disadari, bahwa reaksi sosial publik terhadap Kejahatan Korporasi masih relatif lemah. Barangkali, itulah di antara faktor yang memicu korporasi semakin banyak melakukan eksploitasi, penipuan/pemalsuan, pencemaran, dsb. Untuk itu, menurut Suparman Marzuki, perlu dikembangkan reaksi sosial sebagai model 'counter power' terhadap bentuk kejahatan tersebut, sekaligus ini sebagai antisipasi atas 'kekosongan hukum' saat ini.

\section{Pendahuluan}

STUDI kriminologi tentang kejahatan korporasi (corporate crime) relatif baru, tetapi dalam waktu relatif singkat berkembang menjadi salah satu kajian kriminologi dan perhatian hukum pidana yang sangat penting dan menonjol. Cikal-bakal konsep ini berasal dari perdebatan akademis antara Edwin Sutherland dengan beberapa ahli kriminologi pada masa itu, antara lain Paul W. Tapan menyangkut tulisan Sutherland yang terkenal yaitu "Is white collar crime" (WCC) yang terbit sekitar tahun 1939 dan "crime of corporation" yang terbit tahun 1948. Perdebatan pokok mereka adalah mengenai pengertian person dalam tindak pidana. Dalam karyanya itu
Sutherland mengemukakan bahwa "white collar crime involved conspiracies by members of the wealthy clasess to use their position in commerce and industry for personal gain without regard to the law"1. Secara lebih jelas batasan WCC yang dimaksudkannya adalah " $a$ violation of criminal law by the person of the upper socio-economic class in the course of the occupational activities" $^{2}$ (suatu pelanggaran hukum pidana yang dilakukan oleh orang yang berasal dari kelas sosial ekonomi atas dan dilakukan dalam rangka pekerjaannya).

Dari rumusan itu terlihat bahwa pada awalnya pengertian WCC dibatasi pada perbuatan yang ada dalam rumusan hukum pidana dan tidak menjangkau perbuatan lain di luar apa yang sudah ditentukan dalam hukum 
pidana. Rumusan ini tidak memuaskan dan mengundang perdebatan sebagaimana disinggung di atas dan menghendaki agar cakupan WCC diperluas tidak saja person dalam pengertian natuurlijke persoon tetapi juga dikaitkan dengan mereka yang menjalankan perusahaan (corporation) sehingga pada akhirnya disepakati rumusan WCC ditambah satu unsur lagi, yaitu "violation of trust" (pelanggaran terhadap kepercayaan) yang merupakan unsur penting dalam mengerti apa yang dimaksud dengan "corporate crime" sebagai bagian dari WCC. Perluasan ruang lingkup WCC tersebut menjadikan studi tentang kejahatan korporasi menjadi fokus utama WCC, terutama kajian terbadap potensi dan kecenderungan kejahatan ekonomi ataupun kegiatan yang berkaitan dengan dunia bisnis (business related activities).

\section{Dimensi Kejahatan Korporasi}

DIMENSI kriminal dari kejahatan korporasi di Indonesia berkembang terus seiring dengan perkembangan perekonomian nasional dan internasional. Bentuk-bentuk seperti defrauding stockholders (tidak melaporkan dengan sebenarnya keuntungan perusahaan), defanuding the public (fixing prices dan misrepresenting products), defrauding the goverment (menghindari pajak), endangering the public walfare (menimbulkan polusi), endangering employees (tidak memperdulikan keselamatan kerja), dan illegal intervention in the political process, semakin bervariasi dan berkembang dengan sistem kerja dan operasionalnya yang semakin canggih sehingga sangat sulit pengidentifikasian dan pembukitannya secara hukum.

Perkembangan yang patut dicatat selama paling tidak satu dasawarsa belakangan ini, yang dapat dikatakan "baru", dalam pengertian barı disadari oleh kalangan penegak hukum yaitu apa yang disebut dengan Fraudulent Misrepresentation (FM), yaitu jenis kejahatan korporasi yang bersifat pemberian informasi atau keterangan tidak benar atau bohong tentang aktifitas, produk, perkembangan dan lain-lain dari suatu perusahaan terhadap masyarakat maupun pemerintah. Dari catatan
Ketua Badan Pengawasan Keuangan dan Pem. bangunan (BPKM), Gandhi ${ }^{3}$, paling tidak ada delapan dimensi $F M$. yang sangat menonjol terjadi di Indonesia; empat di antaranya adalah:

Pertama, transfer pricing (TP). TP ini biasanya terjadi pada perusahaan yang tergabung dalam group dan antara satu perusahaan dengan yang lain mempunyai hubungan istimewa. Untuk memperkecil jumlah pajak yang harus dibayar maka harga jual antara group tersebut akan diatur sedemikian rupa sehingga keuntungan dari perusahaan yang untungnya besar akan dipindahkan ke perusahaan yang merugi, sehingga jumlah pajak yang harus dibayar secara keseluruhan (group) akan dapat dikurangi.

Kedua, Over-Under Invoking (OUI). Ini biasanya terjadi pada transaksi impor dan ekspor. Pada transaksi impor, perusahaan bisa meminta rekanannya di luar negeri untuk menerbitkan dua invoice, yaitu satu invoice dengan harga yang sebenarnya untuk kepentingan perhitungan harga pokok, dan invoice satunya lagi dengan harga lebih rendah dipergunakan untuk keperluan pabean (pembayaran bea masuk, PPH pasal 22 dan PPN). Kasus ini bisa terjadi dalam satu atau tanpa adanya hubungan istimewa antara perusahaan pengimpor dengan perusahaan pengekspor. Sedang pada transaksi ekspor, kasus OUI biasanya terjadi berkaitan dengan adanya hubungan istimewa sebagaimana telah diuraikan di atas, yaitu dalam rangka mentransfer keuntungan perusahaan di Indonesia ke perusabaan di luar negeri tanpa terkena Pajak Penghasilan atau deviden (PPH pasal 26).

Ketiga, Afiliasi Tanpa Bunga (ATB). Pada perusahaan yang tergabung dalam group sering terjadi peminjaman kepada Bank dilakukan oleh salah satu atau beberapa perusahaan yang untungnya cukup besar, selanjutnya dana pinjaman tersebut disalurkan kepada perusahaan afiliasi tanpa pembebanan bunga. Dengan cara demikian dapat dilakukan pengaturan laba untuk meminimalkan jumlah pajak secara keseluruhan.

Keempat, keterangan tidak benar dalam pasar modal. Memperhatikan performance finan- 
sial dari perusahaan yang telah go public diperoleh kesan bahwa pada saat akan go public perusahaan itu tampak menguntungkan, setidaknya selama tiga tahun terakhir. Tetapi setelah go public performance keuangannya yang tercermin dalam rugi/laba perusahaan malah jadi menurun. Sedangkan struktur organisasi perusahaan sebelum dan sesudah go public tidak mengalami perubahan. Membandingkan dua keadaan perusahaan sebelum dan setelah go public terdapat indikasi kuat bahwa telah terjadi pemberian informasi yang tidak benar oleh perusahaan itu. Pada saat akan go public perusahaan itu melaporkan keadaan keuangan yang serba baik agar mendapat izin untuk melakukan go public. Setelah perusahaan itu mendapat modal dari masyarakat, dan tidak ada kontrol dari masyarakat tentang operasi dan performance keuangannya, perusahaan itu berusaha membuat dan melaporkan performance keuangan yang rendah agar uang dapat dialihkan ke pengelola dan pemilik perusahaan lama, sedangkan biaya penggunaan modal (cost of capital) yang baru berasal dari masyarakat dapat ditekan serendah mungkin.

Indikasi lain, pada saat performance perusahaan dilaporkan rendah dan kemudian harga dan pasaran sahamnya lesu, pihak pengelola perusahaan dan pemilik mayoritas membeli kembali sahamnya dengan harga yang rendah. Dengan demikian secara tidak langsung terjadi penarikan dana masyarakat dengan biaya murah dan kepemilikan perusahaan tidak berubah.

Bentuk FM dengan tingkat modus operandi yang lebih transparan dan langsung merugikan kepentingan masyarakat adalah pemberian informasi atau iklan bohong atau setidaktidaknya berlebihan tentang nilai, produktivitas, manfaat dan lain-lain dari sebuah atau lebih produk perusahaan. Perkembangan dunia periklanan memang sejalan dengan perubahan kultur perekonomian manusia terutama pergeseran pola produksi, dari subsistensi ke komersial. Maka sesuatu benda tidak lagi dinilai berdasarkan manfaatnya, tetapi nilai tukarnya. Seseorang memproduksi barang atau jasa bukan la- gi (hanya) untuk memenuhi kebutuhan, tetapi untuk diperdagangkan.

Perkembangan ilmu pengetahuan dan teknologi, terutama sejak Revolusi Industri, berbagai jenis barang tidak lagi diproduksi secara parsial untuk memenuhi kebutuhan pasar pada skala kecil, melainkan secara massal. Lebihlebih dengan ditemukannya assembly line, yang dipelopori oleh Henry Ford (1910) pada industri mobilnya di Michigan, pola produksi massal memperoleh dukungan yang luar biasa. Untuk mempertahankan kehidupan sistem dengan pola massal itu tidak ada jalan lain kecuali membentuk pasar yang seluas-luasnya dengan target menjaring konsumen sebanyak-banyaknya. Dalam rangka itu maka harus dirancang ikian yang cermat, dan faktor paling penting adalah selling effect-nya, dengan tujuan mempengaruhi sisi psikologis konsumen, dan bukan akal sehat konsumen sehingga yang dipromosikan adalah harapan dan prestise dengan pengutamaan nilai sekundernya; bukan nilai produknya ${ }^{4}$.

Meskipun secara yuridis formal sulit untuk menentukan kualifikasi dari FM, tetapi secara etis ada dua katagori untuk melihat misrepresentation. Pertama pemakaian pernyataan-pernyataan yang jelas-jelas salah, misalnya menyebut sesuatu yang sebenarnya tidak ada, atau sebaliknya. Kedua adalah pernyataan yang menyesatkan (mislead). Dua istilah lain yang juga digunakan adalah puffery dan mock ups. Yang pertama diartikan sebagai "iklan ber- lebihan" yakni yang menggunakan opini subyektif yang berlebihan tanpa menyebutkan satu fakta tertentu. Contoh puffery adalah penggunaan katakata "nomor satu, terpilih, paling baik... dst". Yang kedua adalah pemakaian tiruan atau mock-ups dalam visualisasi iklan. Contohnya pada iklan es krim untuk TV, yang karena akan meleleh bila terkena panas, saat produksi ia digantikan dengan bubur kentang.

Dimensi lain yang kemungkinan mengandung kejahatan korporasi adalah eksploitasi buruh karena di mana pun dalam suatu negara yang sedang mengalami proses pertumbuhan ekonomi yang pesat, dan terdapat persaingan 
bebas dalam proses produksi dan distribusi sebagaimana sekarang ini kita alami, maka kecenderungan berkembangnya unfair competition sulit dielakkan yang pada akhirnya menjurus kepada berkembangnya monopoli, oligopoli, konsentrasi industri, market limitation, price fuxing misrepresesenting products, mengabaikan ketentuan hukum, tidak mempedulikan keselamatan kerja, dst.

Meski secara yuridis formal sebutan corporate crime belum bisa diterima dalam terminologi yuridis, tetapi secara kriminologis tindakan perusahaan yang mengeksploitasi buruh yang tidak mengindahkan peraturan-peraturan yang menjamin hak-hak buruh dan kewajibankewajiban perusahaan dapat dikatagorikan dalam pengertian criminal behavior atau illegal corporate behavior. Atau kalau kita mengutip diskripsi Marshal B. Clinard menjadi "unfair labour practices involving union right, minimun wage regulations, specific working conditions, and over time; violations of safety regulations related to occupational safety and healt..."

Dalam konteks itu titik rawan buruh justru terletak pada lemahnya posisi tawar mereka terhadap para pengusaha karena adanya kenyataan bahwa buruh kita sangat murah dibandingkan negara-negara lain karena jumlah orang yang ingin bekerja lebih besar daripada lapangan kerja yang tersedia. Perusahaan sadar benar akal hal ini sehingga memanfaatkannya dengan mengeksploitasi buruhnya tanpa mengindahkan hak-hak mereka. Para buruh yang melakukan protes, seringkali dihadapkan kepada dua pilihan; mengundurkan diri atau dijecat, karena di luar masih menunggu ribuan calon buruh yang antri untuk mendapatkan pekerjaan.

Industri-industri luar negeri yang melakukan relokasi di sini pun tertarik pada buruh murah kita karena kita memiliki "keuntungan komparatif" (comparative advantatage), dan ini salah satu sisi menarik yang dijual para pengusaha kita kepada dunia usaha luar negeri untuk menginventasikan modal secara besarbesaran di sini. Padahal menurut Vedi R. Ha$\operatorname{diz}^{6}$, keuntungan komparatif ini justru secara langsung atau tidak langsung merintangi ka- langan buruh untuk berorganisasi secara bebas, guna menyalurkan aspirasi dan keluhan. Sebab, dari sudut pandang tertentu, upah yang terlalu banyak meningkat, permintaan perbaikan kondisi kerja yang terlalu tinggi, kebebasan untuk berorganisasi, dan menyampaikan tuntutan yang terlalu besar -- secara ironis -- akan menggerogoti apa yang dianggap sebagai "keunggulan komparatif" kita itu.

Walau sebenarnya kalau kita mau jujur komponen upah dalam biaya produksi kita masih begitu kecil, sehingga kalaupun dibayarkan upah regional minimum yang dilihat dari dalam negeri cukup memadai, tetapi secara internasional, misalnya dibandingkan dengan $\mathrm{Si}$ ngapura, Korea, bahkan Thailand dan Malaysia, kita masih lebih rendah juga. Jadi secara komparatif kita masih tetap menarik.

Oleh sebab itu sangat diragukan alasan tidak dipatuhinya standar upah minimum, PHK dan tindakan pengabaian hak-hak buruh yang lain karena perusahaan tersebut dalam kondisi turbulence, krisis keuangan, krisis kepemimpinan dalam perusahaan, krisis bahan baku, kebijakan pemerintah dan seterusnya. Boleh jadi corporate crime telah terjalin sedemikian rupa dalam lingkup global, sehingga buruhlah mata rantai paling lemah yang dibebani tugas mengurangi high cost economy dalam hubungan bisnis internasional sekarang ini.

\section{Reaksi Sosial}

KITAB Undang-undang Hukum Pidaha (KUHP) sebagai pelembagaan reaksi sosial formal negara terhadap kejahatan tidak dapat menjaring korporasi sebagai subyek hukum karena yang dapat dipidana atau menjadi subyek hukum dalam KUHP adalah "orang". Meskipun dalam perundang-undangan di luar KUHP, beberapa kejahatan white collar dan subyek hukum korporasi telah diatur, sehingga misalnya perusahaan yang melanggar Ketentuan Upah Minimum (KUM) dapat diajukan ke pengadilan, tetapi peraturannya cenderung bersifat parsial, tidak seimbang, dirumuskan secara tidak baik sehingga penegakan hukumnya kurang efektif.

Serikat Pekerja Seluruh Indonesia (SPSI) yang diharapkan berfungsi sebagai organisasi 
yang memperjuangkan hak-hak mereka pada kenyataannya tidak bisa berbuat banyak. Hingga kini belum terlihat lembaga atau instansi mana yang diakui mampu mengatasi masalah ini. Oleh sebab itu seandainya eksploitasi buruh ini merupakan salah satu bentuk dari "corporate crime" di samping bentuk-bentuk lain, dan kita melihat begitu banyak peluang dilakukannya variasi "corporate crime" di masa-masa mendatang, maka antisipasi hukum pidana masa mendatang pun harus lebih jelas dan tegas.

Buku satu pasal 45 konsep RUU KUHPd yang pernah beredar memang sudak tampak perubahan konstruksi hepotetisnya mengenai "corporate crime". Setidaknya dalam pasal itu sudah tegas dinyatakan bahwa "korporasi merupakan subyek tindak pidana", artinya jika suatu tindak pidana dilakukan oleh atau untuk suatu korporasi, maka penuntutan dapat dilakukan dan pidananya dijatuhkan terhadap korporasi itu sendiri, atau korporasi dan pengurusnya, atau pengurusnya saja (pasal 46). Tetapi ini masih mengundang keraguan akan efektifitas fungsinya mengingat asas yang dipergunakan masih menjadikan hukum pidana sebagai ultimum remidium, di mana hukum pidana tidak akan dipergunakan apabila ada peraturan perundang-undangan lain yang telah memberikan perlindungan yang cukup bagi kepentingan termaksud. Di sinilah titik rawan disfungsionalnya hukum pidana dimaksud.

Menurut hemat kami, penjatuhan pidana terhadap korporasi tentu harus dilakukan secara cermat, berhati-hati dengan kriteria dan batasan yang jelas karena dampaknya bisa sangat luas. Yang akan menderita tidak hanya yang berbuat salah, tetapi pihak-pihak lain seperti pemegang saham, para konsumen, karyawan dan seterusnya. Tetapi menghadapi perkembangan dunia usaha yang demikian itu seyogyanya hukum pidana bisa ditampilkan 'sebagai primum remidium, dan tidak lagi sebagai "ultimum remidium" dengan tetap memegang teguh prinsip kecermatan dan kehati-hatian itu. Karena bagaimanapun jalan law enforcement itu acapkali licin dan berliku-liku yang rawan dengan kemungkinan slip dan kecelakaan, le- bih-lebih bila pintu masuk ke jalan hukum itu sedari awal potensial ke arah itu.

Keterbatasan kemampuan hukum untuk menjaring korporasi secara tegas sebagai pelaku kejahatan tidak lepas dari kelemahan daya represi dan prevensi masyarakat sendiri terhadap kejahatan korporasi. Padahal pengaruh reaksi sosial informal masyarakat terhadap segala bentuk gangguan komunitas terhadap kesungguhan pemerintah dalam melakukan proses kriminalisasi terhadap tindakan-tindakan yang merugikan kepentingan masyarakat akan sangat besar, karena secara fungsional hukum berfungsi melayani dan melindungi kepentingan masyarakat sehingga secara reflektif perubahan atau penambahan kerangka hepotetis hukum itu lebih merupakan respon hukum terhadap kepentingan dan kebutuhan hukum masyarakat itu sendiri.

Perkembangan kriminalisasi atau dekriminalisasi terhadap kecenderungan kejahatan konvensional misalnya, jelas mencerminkan gejolak dan tuntutan masyarakat sendiri akan pengaturan atau penghapusan sejumlah aturan dalam KUHP yang akan datang sebagaimana terlihat dalam perubahan delik-delik Zina, Kejahatan Politik atau kejahatan terhadap kepentingan umum dalam RUU KUHP. Perubahan delik zina ke arah pengaturan yang lebih ketat atau tuntutan tentang perlunya pengaturan santet merupakan reaksi hukum atas kecenderungan tingkat seriusitas reaksi sosial masyarakat terhadap kecenderungan kejahatan itu sendiri.

Oleh sebab itu menghadapi keterbatasan jangkauan hukum terhadap kejahatan korporasi tersebut, seyogyanya dikembangkan satu model pendekatan yang disebut reaksi sosial, berupa membangun persepsi dan sikap kritis masyarakat sebagai pihak yang potensial menjadi korban untuk melihat dan menyadari bahwa kejahatan korporasi yang sering disebut sebagai crime without victim merupakan kejahatan yang memiliki tingkat seriusitas tinggi, yang jauh lebih tinggi dibanding kejahatan kekerasan konvensional. Dengan cara ini diharapkan tumbuh kesadaran dan sikap kehati- 
hatian pihak korporasi di dalam melakukan aktivitas usahanya sehingga tidak melakukan tindakan pelanggaran dan atau kejahatan, di samping mendorong pemerintah untuk segera melakukan kriminalisasi secara jelas dan tegas tanpa ada keraguan.

Tentu saja usaha kriminalisasi dimaksud memerlukan kearifan-kearifan tertentu dari pihak-pihak yang berkompeten melakukan kriminalisasi mengingat dilema masyarakat antara memberlakukan hukum modern dan mempertahankan keutuhan hukum-hukum kebiasaan menimbulkan kesulitan-kesulitan tertentu di tengah-tengah masyarakat karena masih cukup banyak ketentuan-ketentuan hukum kebiasaan yang secara jelas dan tegas bertentangan dengan kebendak hukum modern, seperti misalnya yang menyangkut pengaturan penebangan pohon, hak cipta, eksploitasi sumber daya lingkungan dan seterusnya.

Apabila pelembagaan reaksi sosial informal menjadi reaksi sosial formal itu berhasil dicapai diharapkan pula tercapainya sesuatu yang lebih tinggi dari sekedar mengatasi dilema hukum modern dan hukum kebiasaan, yaitu, tumbuh semangat dan cara pandang hukum masyarakat sesuai dengan semangat dan cara pandang hukum masyarakat modern yang menempatkan kepastian hukum, kemanfaatan sosial hukum dan keadilan sebagai pilar utama penegakan hukum, bukan lagi keseimbangan komunitas sebagaimana yang menjadi pilar utama sebagian besar penegakan hukum kebiasaan. Dengan begitu proses kesadaran hukum masyarakat dapat benar-benar tumbuh dari bawah sebagai bentuk kesadaran hukum yang berorientasi kepada hukum dan bukan kesadaran hukum yang berorientasi kepada pelaksana/ kekuaaan. -

Suparman Marzuki, SH, adalah staf pengajar FH-UII. Alumnus Fakultas Hukum UII. Saat ini menjabat Pembantu Dekan III pada Fakultas yang sama.

\section{Catatan Kaki:}

1. Larry J. Siegel, "Criminology", West Publishing Company, 1986, hal. 362.

2. B. Marjono Reksodiputro, SH, MA, "Pertanggung-jawaban Korupsi dalam Tindak Pidana Korporasi", makalah Seminar Kejahatan Korporasi, UNDIP, 1989, hal. 3.

3. Uraian terperinci dapat dibaca dalam laporan "Forum Keadilan", No. 29, 1991, hal. 22 dst.

4. Uraian menarik tentang ini - yang sebagian dikutip dalam tulisan ini -- dapat dibaca dalam tulisan Zaim Saidi, dalam "Forum Keadilan", ibid, hal. 33.

5. Marshal Clinard, "Corporate Crime", The Free Press, New York, 1980, hal. 168 dst.

6. Kompas, 14 September 1991.

\section{Daftar Pustaka}

1. Larry J. Siegel, "Criminology", West Publishing Company, 1986 , hal. 362.

2. B. Marjono Reksodiputro, SH, MA, "Pertanggung-jawaban Korupsi dalam Tindak Pidana Korporasi", makalah Seminar Kejahatan Korporasi, UNDIP, 1989, hal. 3.

3. Uraian terperinci dapat dicaba dalam laporan "Forum Keadilan", No. 29, 1991, hal. 22 dst.

4. Uaraian menarik tentang ini -- yang sebagian dikutip dalam tulisan ini -- dapat dibaca dalam tulisan Zaim Saidi, dalam "Forum Keadilan", ibid, hal. 33.

5. Marshal Clinard; "Corporate Crime", The Free Press, New York, 1980, hal. 168 dst.

6. Kompas, 14 September 1991. 